\title{
FORMULATION AND PHYSICOCHEMICAL EVALUATION OF VINEGARS PRODUCED FROM MURTA (Ugni molinae TURCZ.) AND MAQUI (Aristotelia chilensis (Molina) Stunz) WITH BEES' HONEY (Apis mellifera L.) AT LABORATORY SCALE
}

\author{
XIMENA ARANEDA DURÁN * \\ SEBASTIÁN CARO SAAVEDRA* \\ MARÍA REYES BRAVO* \\ MARÍA MARTINEZ GUTIÉRREZ*
}

\begin{abstract}
In this study, vinegar was formulated from mixtures of murta (Ugni molinae Turcz.) and maqui (Aristotelia chilensis (Molina) Stunz) with bees' honey (Apis mellifera L.) and its physicochemical characteristics were evaluated with the aim of adding value to these agricultural products and diversifying the supply of gourmet vinegars. Alcoholic fermentation was performed by preparing a must by dissolving honey at $21^{\circ}$ Brix with murta pulp and maqui juice in distilled water, which was enriched with ammonium sulphate and ammonium phosphate. The must was inoculated with Saccharomyces cerevisiae and incubated at $26{ }^{\circ} \mathrm{C}$ to facilitate the action of the yeast. The alcoholic drink was incubated at ambient temperature with Acetobacter aceti bacteria to induce acetic fermentation. The vinegar was clarified, filtered and then stabilised in order to measure total, volatile and fixed acidity, $\mathrm{pH}$, ash and total polyphenols. The results indicated that the physicochemical and functional properties were acceptable and that vinegars made from murta and maqui with honey have market potential.
\end{abstract}

KEY-WORDS: ALCOHOLIC FERMENTATION; ACETIC FERMENTATION; VOLATILE ACIDITY; POLYPHENOLS; VINEGAR.

* Agronomic Engineer, Master of Science in Genetics, Doctor in Agronomic Sciences, Teacher and Researcher, Universidad Católica de Temuco (UCTemuco), Temuco, Chile (e-mail: xaraneda@uct.cl; sebastian.caro.s@live.cl; mreybra2004@alu.uct.cl; mmartine@uct.cl). 


\section{INTRODUCTION}

Vinegar is a consumable liquid which has formed part of human food since the very remote past (SUÁREZ and IÑIGO, 2004). It is widely consumed and is available in all countries and in different varieties (MAZZA and MUROOKA, 2009). It is used principally as a dressing for salads, and also for pickling some meats and vegetables (MADIGAN, MARTINKO and PARKER, 2004). Vinegar is most frequently produced from wine, but it can also be made from substrates such as cider, malt, fruit (apples, pears, grapes, oranges and pineapples), honey, syrups, cereals, rice, hydrolysed starches and even diluted acetic acid (NATERA et al., 2003; BAMFORTH, 2005; SOLIERI and GIUDICl, 2009).

Because these alcoholic liquids are not distilled, they maintain subtle flavours and aromas from their raw materials, which give their vinegars widely-appreciated characteristics (CABALLERO, 2003). Thus, vinegars made from fresh fruits acquire higher sensorial and nutritive qualities (MONSPART-SÉNYI, 2006), because the flavour of these vinegars is influenced by the chemical compounds of the fruits during fermentation (MING, DONG and LI, 2010). This can add further value to the vinegar, since some of the micro-organisms present in the process produce compounds and vitamins which can maintain the health-giving components of the fruit (RASPOR and GORANOVIC, 2008). At the same time, they present a great number of nutritional components in the form of organic acids, amino acids and mineral substances, which play an important role in physiological functions (WANG, 2006).

The consumption of berries has generally been shown to have a positive impact on human health; in the case of Ugni molinae Turcz. and Aristotelia chilensis (Molina) Stunz, these species have a rich and diverse composition with health-promoting bioactive compounds such as phenolic compounds and vitamin C (SCHRECKINGER et al., 2010; RUBILAR et al., 2011). Both these shrubs are native to southern Chile, and have aroused great interest due to the market value of their berries, which have a pleasant flavour and aroma (TABOADA et al., 2010). The astringent, blackish-purple berries of the maqui are also useful as a natural colourant, due to the presence of anthocyanin pigments (ESCRIBANO-BAILÓN et al., 2006).

From a sensorial point of view, one of the most important characteristics of vinegars is their aromatic impact (DURÁN et al., 2007); murta and maqui have good organoleptic characteristics, such as colour, as well as clear, unique flavours (MING, DONG \& LI, 2010). Due to this, and the growing market for fruit vinegars as health food products (OU and CHANG, 2009), there has been a trend towards the development of new products in order to broaden the range of vinegars available on the market.

The objective of this research was to formulate and carry out a physicochemical evaluation of vinegars made from murta and maqui blended with honey as an alternative for adding value to these raw materials and diversifying the supply of gourmet vinegars in Chile.

\section{MATERIAL AND METHODS}

The study was carried out in the Bromatology Laboratory of the Agronomy School of Universidad Católica de Temuco, Chile.

\subsection{RAW MATERIAL}

The raw material for the murta vinegar (U. molinae) was murta pulp, which was prepared from selected fresh fruit. For the maqui vinegar (A. chilensis), maqui juice was used. Both products were blended with multi-flower bees' honey from Southern Chile. For the alcoholic fermentation, a 
pure culture of Saccharomyces cerevisiae Meyen was used in a liquid suspension of water-honey $21^{\circ} \mathrm{Brix}$, with an average concentration $1.05 \times 10^{7} \mathrm{~cm}^{3}$ of yeasts counted in a Neubauer chamber. For the acetic fermentation, Acetobacter aceti bacteria from unpasteurised alcohol vinegar were used (strong vinegar).

\subsection{SUBSTRATE FOR ALCOHOLIC FERMENTATION}

The murta must and maqui juice were prepared by liquidising the fruit and then filtering it to eliminate the seeds. The murta pulp and honey, in equal parts, were mixed with distilled water to obtain a concentration of soluble solids of $21^{\circ} \mathrm{Brix}$. In the case of the maqui, $640 \mathrm{~g}$ of honey were dissolved in $1 \mathrm{~L}$ of maqui juice; this was then mixed with distilled water to reach $21^{\circ}$ Brix, which was determined with a refractometer. To activate fermentation, $0.2 \mathrm{~g} \mathrm{~L}^{-1}$ of ammonium sulphate and $0.02 \mathrm{~g} \mathrm{~L}^{-1}$ of ammonium phosphate (ILHA et al., 2000) were added; the amounts added to the maqui were $0.4 \mathrm{~g} \mathrm{~L}^{-1}$ of ammonium sulphate and $0.05 \mathrm{~g} \mathrm{~L}^{-1}$ of ammonium phosphate. Once a homogenous mixture had been obtained it was placed in glass bottles and then autoclaved for 15 to $20 \mathrm{~min}$ at $121^{\circ} \mathrm{C}$. When the temperature of the enriched must fell to $26^{\circ} \mathrm{C}$, it was inoculated with $100 \mathrm{~mL} \mathrm{~L}^{-1}$ of the S. cerevisiae culture. To encourage alcoholic fermentation, the bottles were incubated in an oven for 2 days at $26{ }^{\circ} \mathrm{C}$. The $\mathrm{pH}$ (3.38) and alcoholic percentage (10\%) were measured.

\subsection{ACETIC FERMENTATION}

Once the alcohol content in the murta must reached $8 \%(\mathrm{v} / \mathrm{v})$, which was determined by an alcoholmeter, $0.1 \mathrm{~g} \mathrm{~L}^{-1}$ of ammonium sulphate, $0.5 \mathrm{~g} \mathrm{~L}^{-1}$ of ammonium phosphate, $0.1 \mathrm{~g} \mathrm{~L}^{-1}$ of potassium citrate and $0.1 \mathrm{~g} \mathrm{~L}^{-1}$ of magnesium sulphate (ILHA et al., 2000) were added to the alcoholic drink. Quantities of $1 \mathrm{~g} \mathrm{~L}^{-1}$ of ammonium phosphate; $0.2 \mathrm{~g} \mathrm{~L}^{-1}$ of ammonium sulphate and $0.2 \mathrm{~g} \mathrm{~L}^{-1}$ of magnesium sulphate were added to the maqui with gentle stirring. Both musts were then inoculated with acetic acid bacteria $(A$. aceti) and fermented at room temperature for one week with oxygenation provided by an oxygen pump.

After both vinegars had been pre-filtered, the murta vinegar was clarified with $90 \mathrm{~g} \mathrm{hL}^{-1}$ of bentonite because it presented turbidity (HIDALGO, 2002). This product favours rapid decanting without altering the composition of the vinegar. Finally, both vinegars were filtered with a vacuum pump using $\mathrm{N}^{\circ} 5 \mathrm{~B}$ filter paper, producing a liquid free of impurities and with a sufficient degree of brilliance.

To prevent $A$. aceti from re-starting the fermentation process, producing turbidity in the bottom of the bottle, or a membrane on the surface, the vinegar was stabilised by pasteurisation in the bottle: the bottled vinegar was immersed in water at $70{ }^{\circ} \mathrm{C}$ for sufficient time to reach a temperature of $66^{\circ} \mathrm{C}$ during 5 minutes. After this process the vinegar is in its final stage and can be stored at room temperature.

\subsection{DETERMINATION OF TOTAL ACIDITY}

Total acidity was determined using neutralisation volumetry in the presence of an alcoholic solution of phenolphthalein as an indicator, based on the method described by PANREAC (1999). A quantity of $10 \mathrm{~mL}$ of previously filtered vinegar was measured in a $250 \mathrm{~mL}$ Erlenmeyer flask. It was diluted with $100 \mathrm{~mL}$ of cold, recently boiled, distilled water and a weakly coloured solution was obtained. Six drops of the phenolphthalein indicator solution were added and it was titled with sodium hydroxide $0.5 \mathrm{~N}$, stirring until the indicator turned. The total acidity or percentage acetic degree of the vinegar was determined using Equation 1: 
Where: "a" corresponds to the volume in $\mathrm{mL}$ of sodium hydroxide $0.5 \mathrm{~N}$.

\subsection{DETERMINATION OF FIXED ACIDITY}

A quantity of $10 \mathrm{~mL}$ of previously filtered vinegar was placed in a porcelain capsule and evaporated completely in a water bath. A quantity of $10 \mathrm{~mL}$ of recently boiled distilled water was added and it was again evaporated completely. This operation was repeated five times. A quantity of $180 \mathrm{~mL}$ of cold, recently boiled distilled water was added; then six drops of phenolphthalein indicator solution were added and it was titled with sodium hydroxide $0.1 \mathrm{M}$, stirring until the indicator turned (PANREAC, 1999). The value of the fixed acidity of the vinegar, expressed in grams of acetic acid per $100 \mathrm{~mL}$, was calculated using Equation 2:

$$
\text { Fixed acidity }=a \times 10 \times 0.006
$$

Where: "a" corresponds to the volume in $\mathrm{mL}$ of sodium hydroxide $0.1 \mathrm{M}$.

\subsection{DETERMINATION OF VOLATILE ACIDITY}

Following the method described by PANREAC (1999), the value of the volatile acidity of the vinegar, expressed in grams of acetic acid per $100 \mathrm{~mL}$, was calculated using Equation 3:

$$
\text { Volatile acidity }=A t-A f
$$

Where: "At" corresponds to total acidity or acetic degree, expressed in grams of acetic acid per $100 \mathrm{~mL}$, and "Af" to the fixed acidity of the same sample of vinegar expressed in grams of acetic acid per $100 \mathrm{~mL}$.

\subsection{DETERMINATION OF pH}

The $\mathrm{pH}$ of the vinegar was measured using a potentiometer (Thomas Scientific, model TS-625) previously calibrated with buffer solutions of $\mathrm{pH} 4$ and $\mathrm{pH} 7$ (VILLA and AGUILAR, 2005).

\subsection{DETERMINATION OF ASH}

The ash content was determined following the method described by PANREAC (1999). A quantity of $20 \mathrm{~mL}$ of vinegar was placed in a capsule which had been weighed empty in an analytical scale, and evaporated carefully in a water bath to a syrupy consistency. Heating was continued in a moderate sand bath for half an hour. The capsule was placed in a muffler at $550^{\circ} \mathrm{C}$. After $5 \mathrm{~min}$ of complete carbonisation, it was removed from the muffler and allowed to $\mathrm{cool}$, and $5 \mathrm{~mL}$ of distilled water was added. This was evaporated in a water bath, and the capsule was again placed in the muffler at $550^{\circ} \mathrm{C}$. After it had been allowed to cool in a desiccator, the capsule was weighed with the ash. Equation 4 was used to calculate the ash content expressed in $\mathrm{g} \mathrm{L}^{-1}$ :

$$
\text { Ash }=50 \times P
$$

Where: "P" corresponds to the weight in $\mathrm{g}$ of the ash content of $20 \mathrm{~mL}$ of vinegar. 


\subsection{DETERMINATION OF TOTAL POLYPHENOLS}

The total polyphenol content was determined using the Folin-Ciocalteu method described by Georgé et al. (2005), using folic acid as the standard, and the results were expressed in $\mathrm{mg}$ equivalents of gallic acid per $100 \mathrm{~mL}$ of vinegar.

\subsection{STATISTICAL ANALYSIS}

The results of the chemical analysis of the vinegar samples were analysed by descriptive statistics (average three repetitions) (MICROSOFT CO., 2007).

\section{RESULTS AND DISCUSSION}

Table 1 shows the results of the physicochemical analyses of the two vinegar formulations.

\subsection{TOTAL ACIDITY}

According to Article 48 of Decree $\mathrm{N}^{\circ} 78$ of Chilean Law $\mathrm{N}^{\circ} 18.455$ (MINISTERIO DE AGRICULTURA, 2010), which fixes norms regarding the production, preparation and commercialisation of ethyl alcohols, alcoholic drinks and vinegars, vinegars in general must comply

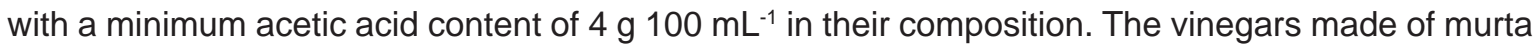
and maqui with honey therefore complied with current Chilean legislation and the results obtained were within the ranges of total acidity for fruit vinegar determined by Chang, Hsiu-Chin and Shau-Mei (2005) and Dogaru et al. (2006). However, although acetic acid is the principal ingredient of vinegar, the total acidity is not a fundamental element for characterising vinegars (ZHANG et al., 2006). For this reason, the addition of honey in the preparation of murta and maqui vinegars gave them a definite, discriminatory value as compared to other groups of vinegars (pineapple, rice, orange), since honey vinegars do not present signs of ethanol in their final preparation, distinguishing them from other vinegars (BOFFO et al., 2009).

TABLE 1 - RESULTS OF PHYSICOCHEMICAL ANALYSES OF VINEGARS MADE FROM MURTA (U. molinae) AND MAQUI (A. chilensis) WITH HONEY

\begin{tabular}{|c|c|c|}
\hline Parameter & Murta & Maqui \\
\hline Total acidity (g $100 \mathrm{~mL}^{-1}$ ) & 4.68 & 5.02 \\
\hline Fixed acidity (g $100 \mathrm{~mL}^{-1}$ ) & 0.29 & 0.17 \\
\hline Volatile acidity (g $100 \mathrm{~mL}^{-1}$ ) & 4.39 & 4.85 \\
\hline $\mathrm{pH}$ & 2.71 & 2.70 \\
\hline Ash $\left(g L^{-1}\right)$ & 0.89 & 2.05 \\
\hline Total polyphenols (mg eq. gallic acid $100 \mathrm{~mL}^{-1}$ ) & 11.74 & 123.70 \\
\hline
\end{tabular}

\subsection{FIXED ACIDITY}

The fixed acidity determined for vinegars made from murta and maqui with honey presented values lower than those reported in wine vinegars (SÁIZ-ABAJO, GONZÁLEZ-SÁIZ and PIZARRO, 
2006). However, the results were within the normal market parameters and complied with Chilean legislation (MINISTERIO DE AGRICULTURA, 2010).

\subsection{VOLATILE ACIDITY}

The values for volatile acidity determined for the vinegars in this study were within the ranges reported in fruit vinegars (PEIXOTO et al., 2010); however, they were lower than those reported by Sáiz-Abajo, González-Sáiz and Pizarro (2006), who obtained volatile acidity values of 5.97 to

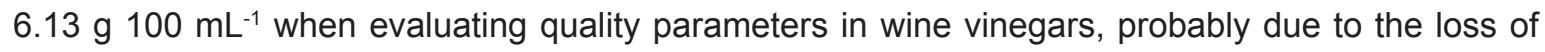
acidity from the bubble-sweeping during oxygenation in acetic fermentation, because this parameter varies with the type and time of fermentation (KOCHER and DHILLON, 2013). Nevertheless, the final product obtained with these native berries presented good organoleptic characteristics, with the colour and flavour characteristic of these fruits. These compensate for the acrid odour of the volatile acidity of vinegars (HIDALGO et al., 2010), which are principally due to acetates formed during alcoholic fermentation (CALLEJÓN et al., 2008) and which have a positive influence on the fruity aroma of the compounds (SU and CHIEN, 2010; MARRUFO-CURTIDO et al., 2012), contributing both flavour and aroma (ZHANG et al., 2006).

\section{$3.4 \mathrm{pH}$}

The vinegars made of murta and maqui with honey were within the normal ranges reported in fruit vinegars (CHANG, HSIU-CHIN and SHAU-MEI, 2005; PEIXOTO et al., 2010) and native vinegars ( $\mathrm{pH}$ 2.2) (DI GIROLAMO, D'AMATO and RIGHETTI, 2011). However, the production process used to prepare vinegars should be considered because, depending on the technological process, there may be a risk of incomplete acetification (HIDALGO et al., 2010).

\subsection{ASH}

According to Article 48 of Decree $\mathrm{N}^{\circ} 78$ of Chilean Law $\mathrm{N}^{\circ} 18.455$ (MINISTERIO DE AGRICULTURA, 2010), the ash content in vinegar cannot be less than $1 \mathrm{~g} \mathrm{~L}^{-1}$. Vinegar made of murta with honey would not comply with this regulation and would be outside the range for wine vinegars (SÁIZ-ABAJO, GONZÁLEZ-SÁIZ and PIZARRO, 2004; 2006). However, the vinegar made from maqui with honey would comply with the Chilean regulation and the ranges presented by SáizAbajo, González-Sáiz and Pizarro (2004) and Peixoto et al. (2010).

\subsection{TOTAL POLYPHENOLS}

According to a study by Peixoto et al. (2010), the honey content in the formulation of vinegar contributes an increase of around $50 \%$ to the total polyphenol content. This is because fermentation increases the extraction of phenols (SACCHI, BISSON and ADAMS, 2005), while other phenols form during fermentation (PLATA et al., 2003). However, the source of the honey used must be considered, since the composition of honeys varies widely, depending on the species of bee which produces it, the floral and geographical origin, the harvest and climatic conditions (PEREIRA, QUEIROZ and DE FIGUEIREDO, 2003; QUEIROZ et al., 2007). The same occurs with maqui and murta berries, where the genotype is the principal factor affecting the polyphenol content (FREDES et al., 2012), together with the different climatic conditions where the plants grow (GAMBELLI and SANTARONI, 2004; REYES-CARMONA et al., 2005; ROBBINS et al., 2005; SHENE et al., 2009).

The difference in the quantity of phenolic compounds in red and white wines is not only due to the presence of anthocyanins, but also to the manufacturing process by which the wine is obtained; this would partly explain the values obtained for the vinegar made from murta with honey, 
since it contains few anthocyanin pigments, and presents a colour which would put it in the category of white wine vinegars. On the other hand, the vinegar made from maqui with honey presented a higher polyphenol content, since the berries have a significantly higher polyphenol content and antioxidant capacity than other Chilean berries (FREDES, 2009), as well as being rich in anthocyanins (ESCRIBANO-BAILÓN et al., 2006). This agrees with Pinsirodom, Rungcharoen and Liymminful (2010), who mention that in general, samples of darker coloured vinegars tend to present a greater total polyphenol content and antioxidant capacity, due to the raw materials used.

Another possible reason why the vinegar made from murta and honey presented values below the range for total polyphenols compared to other vinegars (NATERA et al., 2003; DÁVALOS, BARTOLOMÉ and GÓMEZ-CORDOVÉS, 2005) might be the manner in which the latter are stored. According to Tesfaye et al. (2002), the value of this parameter increases in all vinegars during ageing because a large quantity of phenolic compounds is extracted from the barrel. However, the contact of the vinegars with wood is not very significant for their polyphenol content, because the presence of these compounds is principally due to the raw material used in production, as in the case of wine vinegars, where these have a greater influence (ALONSO et al., 2004). Despite this, the vinegar made from maqui with honey was within the ranges reported by Kocher and Dhillon (2013), who

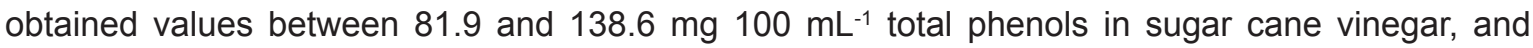
presented higher values than those reported by Peixoto et al. (2010) in vinegar made of orange

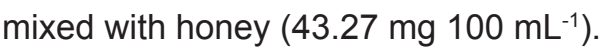

Thus, both these native berries have a potential for use in vinegar production, with added value for this product based on their polyphenol content, colour and aroma, since consumers are interested in obtaining health benefits from foods and demand products with new characteristics. The principal raw materials for such products are fruits and vegetables (UBEDA et al., 2011), and their most attractive aspect is the consumption of natural antioxidants (especially phenolic compounds) and health-promoting substances (DÁVALOS, BARTOLOMÉ and GÓMEZ-CORDOVÉS, 2005).

\section{CONCLUSION}

It was possible to produce vinegars from murta and maqui with honey, using commercial yeasts and acetic bacteria as inocula under laboratory conditions. Vinegar production is an alternative for adding value to these three raw materials.

Although none of the levels for the physicochemical properties of vinegar made from murta with honey was notably higher than found in the literature, all were within the normal range and complied with the law, except the ash content, which in the case of murta vinegar was below the level required by Chilean legislation. Under chemical analysis, the vinegar made from maqui with honey presented acceptable characteristics in all the evaluated parameters, thus complying with Chilean legislation.

\section{RESUMO}

\section{FORMULAÇÃO E AVALIAÇÃO FÍSICO-QUÍMICA DE VINAGRES DE MURTA (Ugni molinae TURCZ.) E MAQUI (Aristotelia chilensis (MOLINA) STUNZ) COM MEL DE ABELHAS (Apis mellifera L.) EM ESCALA DE LABORATÓRIO}

Avaliaram-se as características físico-químicas de vinagres obtidos a partir da mistura de murta (Ugni molinae Turcz.) e maqui (Aristotelia chilensis (Molina) Stunz), adicionados com mel de abelhas (Apis mellifera L.), visando agregar valor à esses produtos agrícolas e diversificar a oferta de vinagres gourmet. Preparou-se o mosto para a fermentação alcoólica, dissolvendo a polpa de murta, o suco de maqui e o mel em água destilada até se obter concentração de sólidos solúveis de $21^{\circ}$ Brix. Visando o enriquecimento do mosto acrescentou-se sulfato de amônio e fosfato de amônio. O mosto foi inoculado com Saccharomyces cerevisiae e incubado a $26^{\circ} \mathrm{C}$ para facilitar a ação das leveduras. A bebida alcoólica resultante desse processo foi incubada à temperatura ambiente com bactérias Acetobacter aceti para induzir o processo de fermentação acética. $\mathrm{O}$ vinagre foi 
clarificado, filtrado e depois estabilizado, sendo submetido às determinações da acidez total, fixa e volátil, pH, cinzas e polifenois totais. De acordo com os resultados das análises o produto apresentou propriedades físicoquímicas e funcionais adequadas, indicando perspectivas de mercado para o vinagre elaborado com maqui, murta e mel.

PALAVRAS-CHAVE: VINAGRE; FERMENTAÇÃO ALCOÓLICA; FERMENTAÇÃO ACÉTICA; ACIDEZ VOLÁTIL; POLIFENOIS.

\section{REFERENCES}

1 ALONSO, Á.; CASTRO, R.; RODRÍGUEZ, M.; GUILLÉN, D.; BARROSO, C. Study of the antioxidant power of brandies and vinegars derived from sherry wines and correlation with their content in polyphenols. Food Research International, v.37, p.715-721, 2004.

2 BAMFORTH, C.W. Food, fermentation and micro-organisms. Davis, USA: Blackwell Science, University of California, 2005. $216 \mathrm{p}$.

3 BOFFO, E.; TRAVARES, L.; FERREIRA, M.; FERREIRA, A. Classification of Brazilian vinegars according to their $1 \mathrm{H}$ NMR spectra by pattern recognition analysis. LWT-Food Science and Technology, v.42, p.1455-1460, 2009.

4 CABALLERO, B. Encyclopedia of food sciences and nutrition. Baltimore, Maryland, USA: Academic Press, 2003. 6289 p.

5 CALLEJÓN, R.M.; MORALES, M.L.; SILVA FERREIRA, A.C.; TRONCOSO, A.M. Defining the typical aroma of sherry vinegar: sensory and chemical approach. Journal of Agricultural and Food Chemistry, v.56, p.8086-8095, 2008.

6 CHANG, R.C.; HSIU-CHIN, L.; SHAU-MEI, A. Investigation of the physicochemical properties of concentrated fruit vinegar. Journal of Food and Drug Analysis, v.13, n.4, p.348-356, 2005

7 DÁVALOS, A.; BARTOLOMÉ, B.; GÓMEZ-CORDOVÉS, C. Antioxidant properties of commercial grape juices and vinegars. Food Chemistry, v.93, n.2, p.325-330, 2005.

8 DOGARU, D.; POIANA, M.; MOIGRADEAN, D.; HADARUGA, N. Processing and characterization of some flavored vinegars. Journal of Agroalimentary Processes and Technologies, v.12, n.1, p.27-36, 2006.

9 DI GIROLAMO, F.; D'AMATO, A.; RIGHETTI, P. Horam nonam exclamavit: sitio. The trace proteome of your daily vinegar. Journal of Proteomics, v.75, p.718-724, 2011.

10 DURÁN, E.; NATERA, R.; CASTRO, R.; BARROSO, C.G. Stir bar sorptive extraction of volatile compounds in vinegar: validation study and comparison with solid phase microextraction. Journal of Chromatography A, v.1167, p. 18-26, 2007

11 ESCRIBANO-BAILÓN, M.T.; ALCALDE-EON, C.; MUÑOZ, O.; RIVAS-GONZALO, J.C.; SANTOS-BUELGA, C. Anthocyanins in berries of maqui (Aristotelia chilensis (Mol. Stuntz)). Phytochemical Analysis, v.17, p.8-14, 2006.

12 FREDES, C. Antioxidantes en berries nativos chilenos. Boletín Latinoamericano y del Caribe de Plantas Medicinales y Aromáticas, v.8, n.6, p.469-478, 2009

13 FREDES, C.; MONTENEGRO, G.; ZOFFOLI, J.P.; GÓMEZ, M.; ROBERT, P. Polyphenol content and antioxidant activity of maqui (Aristotelia chilensis [Molina] Stuntz) during fruit development and maturation in Central Chile. Chilean Journal of Agricultural Research, v.72, n.4, p.582-589, 2012.

14 GAMBELLI, L.; SANTARONI, G.P. Polyphenols content in some Italian red wines of different geographical origins. Journal of Food Composition and Analysis, v.17, p.613-618, 2004.

15 GEORGÉ, S.; BRAT, P.; ALTER, P.; AMIOT, M.J. Rapid determination of polyphenols and vitamin C in plant derived products. Journal of Agricultural and Food Chemistry, v.53, p.1370-1373, 2005.

16 HIDALGO, C.; MATEO, E.; CEREZO, A.B.; TORIJA, M.J.; MAS, A. Technological process for production of persimmon and strawberry vinegars. International Journal of Wine Research, v.2, p.55-61, 2010.

17 HIDALGO, J. Tratado de enología. Madrid, España: Mundi Prensa, 2002. v. 2.

18 ILHA, E.C.; SANT'ANNA, E.; TORRES, R.C.; PORTO, A.C.; MEINERT, E.M. Utilization of bee (Apis mellifera) honey for vinegar production at laboratory scale. Acta Científica Venezolana, v.51, n.4, p.231-235, 2000

19 KOCHER, G.; DHILLON, H. Fermentative production of sugarcane vinegar by immobilized cells of Acetobacter aceti under packed bed conditions. Sugar Tech, v.15, n.1, p.71-76, 2013

20 MADIGAN, M.; MARTINKO, J.; PARKER, J. Brock, biología de los microorganismos. $10^{\text {th }}$ ed. Illinois, USA: Prentice Hall, 2004. 1011 p. 
21 MARRUFO-CURTIDO, A.; CEJUDO-BASTANTE, M.J.; DURÁN-GUERRERO, E.; CASTRO-MEJÍAS, R.; NATERAMARÍN, R.; CHINNICI, F.; GARCÍA-BARROSO, C. Characterization and differentiation of high quality vinegars by stir bar sorptive extraction coupled to gas chromatography-mass spectrometry (SBSE-GC-MS). LWT- Food Science and Technology, v.47, p.332-341, 2012.

22 MAZZA, S.; MUROOKA, Y. Vinegars through the ages. In: SOLIERI, L.; GIUDICI, P. Vinegars of the world. Milan: Springer-Verlag, 2009. p. 17-39.

23 MICROSOFT CORPORATION. Microsoft office - Exel 2007. Barcelona: Ediciones EN, 2007. 124 p.

24 MINISTERIO DE AGRICULTURA. Ley Número 18.455. Santiago, Chile: Servicio Agrícola y Ganadero (SAG), 2010.77 p.

25 MING, H.; DONG, R.; LI, G. Research on vinegar fermentation of strawberry with compound condiments. Journal of Anhui Agricultural Sciences, v.15, p.8186-8188, 2010.

26 MONSPART-SÉNYI, J. Fruit processing waste management. In: HUI, Y.H. Handbook of fruits and fruit processing. lowa: Blackwell Publishing, 2006. p. 205-215.

27 NATERA, R.; CASTRO, R.; GARCÍA-MORENO, M.V.; HERNÁNDEZ, M.J.; GARCÍA-BARROSO, C. Chemometric studies of vinegars from different raw materials and processes of production. Journal of Agricultural and Food Chemistry, v.51, p.3345-3351, 2003.

28 OU, A.S.M.; CHANG, R.C. Taiwan fruit vinegar. In: SOLIERI, L.; GIUDICI, P. Vinegars of the world. Milan: SpringerVerlag, 2009. p. 223-241.

29 PANREAC Química S.A. Métodos analíticos en alimentaria: productos derivados de la uva, aguardientes y sidras. Barcelona, España, 1999. 196 p.

30 PEIXOTO, F.; SPINOSA, W.; FERNANDES, K.F.; DE SOUZA, C.F.; CALIARI, M. Padrões de identidade e qualidade de fermentados acéticos comerciais de frutas e vegetais. Ciencia e Tecnología de Alimentos, v.30, n.1, p.119-126, 2010

31 PEREIRA, E.A.; QUEIROZ, A.J.; DE FIGUEIREDO, R.M. Comportamento reológico de mel de abelha urucú (Melipona scutellaris L.). Revista de Ciências Exatas e Naturais, v.5, n.2, p.179-186, 2003.

32 PINSIRODOM, P.; RUNGCHAROEN, J.; LIYMMINFUL, A. Quality of commercial wine vinegars evaluated on the basis of total polyphenol content and antioxidant properties. Asian Journal of Food and Agro-Industry, v.3, n.4, p.389-397, 2010.

33 PLATA, C.; MILLAN, C.; MAURICIO, J.C.; ORTEGA, J.M. Formation of ethyl acetate and iso-amyl acetate by various species of wine yeasts. Food Microbiology, v.20, p.217-224, 2003.

34 QUEIROZ, A.J.; DE FIGUEIREDO, R.; DA SILVA, C.; MATA, M.E. Comportamento reológico de méis de florada silvestre. Revista Brasileira de Engenharia Agrícola e Ambiental, v.11, n.2, p.190-194, 2007.

35 RASPOR, P.; GORANOVIC, D. Biotechnological applications of acetic acid bacteria. Critical Reviews in Biotechnology, v.28, n.2, p.101-124, 2008.

36 REYES-CARMONA, J.; YOUSEF, G.G.; MARTÍNEZ-PENICHE, R.A.; LILA, M.A. Antioxidant capacity of fruits extracts of blackberry (Rubus sp.) produced in different climatic regions. Journal of Food Science, v.70, n.7, p.S497-S503, 2005.

37 ROBBINS, R.J.; KECK, A.S.; BANUELOS, G.; FINLEY, J.W. Cultivation conditions and selenium fertilization alter the phenolic profile, glucosinolate, and sulforaphane content of broccoli. Journal of Medicinal Food, v.8, p.204-214, 2005.

38 RUBILAR, M.; JARA, C.; POO, Y.; ACEVEDO, F.; GUTIERREZ, C.; SINEIRO, J.; SHENE, C. Extracts of maqui (Aristotelia chilensis) and murta (Ugni molinae Turcz.): sources of antioxidant compounds and a-Glucosidase/a-Amylase inhibitors. Journal of Agricultural and Food Chemistry, v.59, n.5, p.1630-1637, 2011.

39 SACCHI, K.L.; BISSON, L.F.; ADAMS, D.O. A review of the effect of winemaking techniques on phenolic extraction in red wines. American Journal of Enology and Viticulture, v.56, p.197-206, 2005.

40 SÁIZ-ABAJO, M.J.; GONZÁLEZ-SÁIZ, J.M.; PIZARRO, C. Classification of wine and alcohol vinegar samples based on near-infrared spectroscopy. Feasibility study on the detection of adulterated vinegar samples. Journal of Agricultural and Food Chemistry, v.52, p.7711-7719, 2004.

41 SÁIZ-ABAJO, M.J.; GONZÁLEZ-SÁIZ, J.M.; PIZARRO, C. Prediction of organic acids and other quality parameters of wine vinegar by near-infrared spectroscopy. A feasibility study. Food Chemistry, v.99, n.3, p.615-621, 2006.

42 SCHRECKINGER, M.E.; LOTTON, J.; LILA, M.A.; DE MEJIA, E.G. Berries from South America: a comprehensive review on chemistry, health potential, and commercialization. Journal of Medicinal Food, v.13, n.2, p.233-246, 2010.

43 SHENE, C.; REYES, A.; VILLARROEL, M.; SINEIRO, J.; PINELO, M.; RUBILAR, M. Plant location and extraction 
procedure strongly alter the antimicrobial activity of murta extracts. European Food Research and Technology, v.228, p.467-475, 2009

44 SOLIERI, L.; GIUDICI, P. Vinegars of the world. Milan, Italy: Springer-Verlag, 2009. 297 p.

45 SUÁREZ, J.; IÑIGO, B. Microbiología enológica: fundamentos de vinificación. 3. ed. Madrid, España: Mundi-Prensa, 2004. $714 \mathrm{p}$.

46 SU, M.S.; CHIEN, P.J. Aroma impact components of rabbit-eye blueberry (Vaccinium ashei) vinegars. Food Chemistry, v.119, p.923-928, 2010.

47 TABOADA, E.; FISHER, P.; JARA, R.; ZÚÑIGA, E.; GIDEKEL, M.; CABRERA, J.C.; PEREIRA, E.; GUTIÉRREZMORAGA, A.; VILLALONGA, R.; CABRERA, G. Isolation and characterization of pectic substances from murta (Ugni molinae Turcz.) fruits. Food Chemistry, v.123, p.669-678, 2010.

48 TESFAYE, W.; MORALES, M.L.; GARCÍA-PARRILLA, M.C.; TRONCOSO, A. Evolution of phenolic compounds during an experimental aging in wood of sherry vinegar. Journal of Agricultural and Food Chemistry, v.50, p.7053-7061, 2002.

49 UBEDA, C.; CALLEJÓN, R.M.; HIDALGO, C.; TORIJA, M.J.; MAS, A.; TRONCOSO, A.M.; MORALES, M.L. Determination of major volatile compounds during the production of fruit vinegars by static headspace gas chromatography-mass spectrometry method. Food Research International, v.44, p.259-268, 2011.

50 VILLA, M.; AGUILAR, J. Manual de prácticas química inorgánica. Medellín, Colombia: Universidad de Medellín, 2005. $133 \mathrm{p}$.

51 WANG, T.Y. The functionality of fruit vinegar. China Condiment, v.6, p.10-12, 2006.

52 ZHANG, Q.; ZHANG, S.; XIE, CH.; ZENG, D.; FAN, CH.; LI, D.; BAI, Z. Characterization of Chinese vinegars by electronic nose. Sensors and Actuators B: Chemical, v.119, p.538-546, 2006. 